\title{
Effect of Current Ratio and Debt to Equity Ratio on Price to Book Value with Return on Equity as a Mediation Variable in Property, Real Estate and Building Construction Sector Companies on the Indonesia Stock Exchange for the Period 2016-2018
}

\author{
Lina Minah ${ }^{1}$, Nagian Toni ${ }^{2}$, Enda Noviyanti Simorangkir ${ }^{3}$, \\ Galumbang Hutagalung ${ }^{4}$ \\ 1,2,3,4 Universitas Prima Indonesia, Indonesia \\ Corresponding Author: Nagian Toni
}

\begin{abstract}
The purpose of this study was to determine and analyze the effect of current ratio (CR) and debt to equity ratio (DER) on price to book value (PBV) with return on equity (ROE) as a mediation variable in Property, Real Estate and Building Construction Sector Companies on the Indonesia Stock Exchange for the Period 20162018. This research was conducted on Property, Real Estate and Building Construction Sector Companies listed on the Indonesia Stock Exchange in 2016-2018. This research was conducted on Property, Real Estate and Building Construction Sector Companies listed on the Indonesia Stock Exchange in 2016-2018. The population in this study is the Property, Real Estate and Building Construction Sector Companies that have gone public and are listed on the Indonesia Stock Exchange for the 20162018 period, with a total of 81 companies. The research populations according to the purposive sampling criteria were 44 companies. Hypothesis testing is done by statistical test $\mathrm{t}(\mathrm{t}-$ test). Based on the results of hypothesis testing conducted with the SmartPLS tool, CR has significant effect on PBV in Property, Real Estate and Building Construction Sector Companies on the Indonesia Stock Exchange for the Period 2016-2018. DER has an significant effect on PBV in Property, Real Estate and Building Construction Sector Companies on the Indonesia Stock Exchange for the Period 20162018. CR has significant effect on ROE in
\end{abstract}

Property, Real Estate and Building Construction Sector Companies on the Indonesia Stock Exchange for the Period 2016-2018. DER has no significant effect on ROE in Property, Real Estate and Building Construction Sector Companies on the Indonesia Stock Exchange for the Period 2016-2018. ROE has significant effect on PBV in Property, Real Estate and Building Construction Sector Companies on the Indonesia Stock Exchange for the Period 20162018. ROE has significant effect on mediating the effect of the CR on PBV in Property, Real Estate and Building Construction Sector Companies on the Indonesia Stock Exchange for the Period 2016-2018. ROE has no effect in mediating the effect of the DER on PBV in Property, Real Estate and Building Construction Sector Companies on the Indonesia Stock Exchange for the Period 2016-2018.

Keywords: Current Ratio, Debt to Equity Ratio, Price to Book Value, Return on Equity

\section{INTRODUCTION}

There are several purposes of establishing a company, the first goal is to achieve maximum profit. The second goal is to prosper the owner of the company or the shareholders. While the third goal of the company is to maximize the value of the company that can be reflected in the company's stock price. The three objectives 
Lina Minah et.al. Effect of current ratio and debt to equity ratio on price to book value with return on equity as a mediation variable in property, real estate and building construction sector companies on the Indonesia stock exchange for the period 2016-2018.

of the company are actually not substantially different.

The purpose of the company according to the view of financial management, is basically to optimize the value of the company. Firm value is an investor's perception of the company's level of success which is closely related to its share price. High stock prices make the value of the company also high and increase market confidence not only in the company's current performance but also on the company's prospects in the future.

Maximizing the value of a company is a goal that is very relevant in this era of very tight business competition, especially companies that have gone public. The purpose of companies going public in terms of maximizing the value of the company is to maximize the value of the company's shares. Whether or not this objective is achieved can be seen and measured from the share price of the company concerned from time to time.

The results of data processing using the price to book value (PBV) can be seen in the data, which is a value of less than 1 , it is found to increase every year from $39 \%$ in 2016 to $50 \%$ in 2017 and to $61 \%$ in 2018 . The number of price values to book value PBV below 1 illustrates that the company's shares in the property, real estate and building construction sector are undervalued, which means that the company's shares are valued lower than their book value. In fact, the higher the PBV means the market believes in the company's prospects. Thus, a decrease in the value of PBV will have an effect on decreasing the welfare of shareholders. Firm value is very important because it reflects the company's performance which can affect investors' perceptions of the company. Increased company value can be achieved if there is cooperation between company management and other parties including shareholders and stakeholders in making financial decisions with the aim of maximizing shareholder welfare (Brigham and Houston, 2006:19).
Business competition in Indonesia is currently experiencing development. It can be proven that based on data from the Indonesia Stock Exchange (IDX) until the end of 2017 there were a total of 555 companies that had listed their shares on the capital market or went public, including 48 companies in the Property, Real Estate and Building Construction Sectors, with a total of 48 companies in the Property, Real Estate and Building Construction Sectors. Property, Real Estate and Building Construction Sector Companies listed on the Indonesia Stock Exchange show that one of the investment businesses that is booming in Indonesian society today is investing money in land or property which has resulted in the property, real estate and building construction sector industries continuing to grow rapidly and more and more. companies that take part in exploiting this opportunity.

The Property, Real Estate and Building Construction Sectors is a very lucrative business. The population of Indonesia is very large, requiring a place to live that must be met. This is a very good business opportunity, therefore the property, real estate and building construction sector business is very developed in Indonesia. Another supporting factor in developing property, real estate and building construction sector companies is land prices that continue to increase, especially in big cities. with a very dense population and increasing every year, as well as the price of buildings or properties that are relatively stable and the possibility of decreasing is very low unless there is certain damage.

Current ratio (CR) is the ability of the company's current assets to meet shortterm obligations with current assets owned. In other words, the $\mathrm{CR}$ is a ratio that measures the company's ability to meet its short-term obligations. A company can be said to have a strong financial position if the company can meet its short-term obligations. This CR measures the level of liquidity in a company, the more liquid a company is, the higher its $\mathrm{CR}$ will be. The 
Lina Minah et.al. Effect of current ratio and debt to equity ratio on price to book value with return on equity as a mediation variable in property, real estate and building construction sector companies on the Indonesia stock exchange for the period 2016-2018.

higher the level of liquidity, the higher the CR. With a high level of $\mathrm{CR}$ reflects the adequacy of cash so that the more liquid a company is, the level of investor confidence will increase this will improve the image of the company in the eyes of investors so that it can affect the company value (PBV).

Regarding the research that has been carried out, from several studies conducted related to the $\mathrm{CR}$ to $\mathrm{PBV}$, it shows consistent results that have a significant positive effect, including research conducted by Dunanti et al. (2017) and Sutrisno and Yulianeu (2017) consistently conclude that the $\mathrm{CR}$ has a positive and significant effect on PBV. While some researchers also concluded that there was no significant effect, including research conducted by Uzliawati et al. (2016) and Hasibuan (2016).

The high and low value of the CR affects the company's profitability. This ratio describes the ability of current assets to cover debt maturing in less than one year. The high value of the $\mathrm{CR}$ has an impact on creditors because it is concluded that all obligations can be paid off. A low $\mathrm{CR}$ value will be risky but shows the company is using current assets effectively to generate profits. The CR describes the ability of current assets to cover debt maturing in less than one year. The high value of the CR has an impact on creditors because it is concluded that all obligations can be paid off, and gives a good assessment for the company. A low $\mathrm{CR}$ value will be risky but shows the company is using current assets effectively to generate profits.

From several studies conducted related to the $\mathrm{CR}$ on return on equity (ROE), it shows consistent results that have a significant effect, including research conducted by Isnarno (2012) consistently concludes the results that the $\mathrm{CR}$ has a significant effect on ROE. While some researchers concluded that it had no significant effect, including research conducted by Pongrangga et al. (2015),
Sudaryo and Pratiwi (2016) and Puteh (2013).

The high debt to equity ratio (DER) value also affects the company's PBV and ROE. DER is very influential on the company's profitability, because this ratio explains the company's ability to meet its long-term obligations. Companies that are growing will require more budgets from various parties for operational activities which greatly affect the profitability of the company. If the company's external sources of funds are ignored and allowed to increase, there will be a decrease in the company's profitability because it causes interest expenses to increase and does not have a good impact on the company or affect the PBV value.

Regarding the research that has been done, from several studies conducted related to the $\mathrm{CR}$ to PBV value, showing consistent results, namely a significant positive effect, including research conducted by Dunanti et al. (2017) and Sutrisno and Yulianeu (2017) are consistent. Concludes the results that the $\mathrm{CR}$ has a positive and significant effect on PBV. While some researchers also concluded that there was no significant effect, including research conducted by Uzliawati et al. (2016) and Hasibuan (2016).

The high and low value of the CR affects the company's profitability. This ratio describes the ability of current assets to cover debt maturing in less than one year. The high value of the CR has an impact on creditors because it is concluded that all obligations can be paid off. A low CR value will be risky but shows the company is using current assets effectively to generate profits. The CR describes the ability of current assets to cover debt maturing in less than one year. The high value of the CR has an impact on creditors because it is concluded that all obligations can be paid off, and gives a good assessment for the company. A low $\mathrm{CR}$ value will be risky but shows the company is using current assets effectively to generate profits.

The high DER value also affects the company's PBV and ROE. DER is very 
Lina Minah et.al. Effect of current ratio and debt to equity ratio on price to book value with return on equity as a mediation variable in property, real estate and building construction sector companies on the Indonesia stock exchange for the period 2016-2018.

influential on the company's profitability, because this ratio explains the company's ability to meet its long-term obligations. Companies that are growing will require more budgets from various parties for operational activities which greatly affect the profitability of the company. If the company's external sources of funds are ignored and allowed to increase, there will be a decrease in the company's profitability because it causes interest expenses to increase and does not have a good impact on the company or affect the PBV value.

The purpose of this study was to determine and analyze the effect of current ratio (CR) and debt to equity ratio (DER) on price to book value (PBV) with return on equity (ROE) as a mediation variable in Property, Real Estate and Building Construction Sector Companies on the Indonesia Stock Exchange for the Period 2016-2018.

\section{RESEARCH METHODS}

This research was conducted on Property, Real Estate and Building Construction Sector Companies listed on the Indonesia Stock Exchange in 2016-2018.

The population in this study is the Property, Real Estate and Building Construction Sector Companies that have gone public and are listed on the Indonesia Stock Exchange for the 2016-2018 period, with a total of 81 companies. According Pandiangan et al. (2018) in Sugiyono, purposive sampling is the selection of samples based on certain characteristics that are considered to have relevance to the characteristics of the population that have been known previously. The research population according to the purposive sampling criteria were 44 companies. Library research is a form of research that uses library facilities by examining theoretical discussions from various books, articles, and scientific works related to writing (Pandiangan, 2018).

Hypothesis testing is done by statistical test $\mathrm{t}$ (t-test). If in this test the $\mathrm{p}$ value is $<0.05(\alpha=5 \%)$, it means that the test is significant, and conversely if the pvalue is $>0.05(\alpha=5 \%)$, it means that it is not significant.

\section{RESULT \\ General Description}

The Indonesian Stock Exchange (IDX) is a government agency that acts as the organizer of the stock exchange. This means that the Indonesia Stock Exchange is tasked with facilitating securities trading in Indonesia. The Indonesian Stock Exchange is based in the Indonesia Stock Exchange Building, Kawasan Niaga Sudirman, Jalan Jenderal Sudirman 52-53, Senayan, Kebayoran Baru, Jakarta Selatan.

The Indonesia Stock Exchange is the official stock exchange in Indonesia, so companies that want to go public in Indonesia must go through the IDX. The Indonesia Stock Exchange must also control the process of securities transactions that occur fairly and efficiently. Prevent the practice of unfair price manipulation, which is prohibited by law. Conduct trading freeze/suspend for issuers of shares that violate the provisions of the stock exchange. Revocation of securities/delisting, in accordance with applicable regulations.

With the IDX as the organizer of the stock exchange, one of the reasons why investing in shares in Indonesia is a safe instrument. This is because the IDX has authority over the members of the stock exchange and listed issuers.

The first stock exchange was established in Batavia. At that time, the Dutch established a massive plantation business, and required a lot of capital from various European investors. At that time, the income of the European population was 50 to 100 times that of the indigenous population. A Stock Exchange was also established in Batavia with the aim of raising funds from the European community. After the preparations were complete, the Vereniging Voor de Effectenhandel (Stock Exchange) was established, and at the same time started trading securities on December 14, 1912. At 
Lina Minah et.al. Effect of current ratio and debt to equity ratio on price to book value with return on equity as a mediation variable in property, real estate and building construction sector companies on the Indonesia stock exchange for the period 2016-2018.

this time, there are 13 active Exchange Members. The securities traded are shares and bonds of Dutch plantation companies. The development of the Stock Exchange company in Batavia was also very rapid. But in this era also experienced ups and downs when the second world war (World War II). All securities transaction activities were closed on May 10, 1940. This made it difficult for securities owners to sell their securities, and caused many brokerage companies to close. The outbreak of the second world war also marked the end of the activities of the Stock Exchange in the Dutch era.

A year after the Dutch government recognized the sovereignty of the Republic of Indonesia, namely in 1950, the government finally issued bonds. This marked the re-activation of capital market activities in Indonesia. Finally, on June 30, 1952, the Indonesia Stock Exchange was reopened in Jakarta. The implementation was handed over to the Money and Securities Trading Union (PPUE). Since this too, the Stock Exchange has grown rapidly again in Indonesia. However, this situation only lasted until 1958. As a result of politics and disputes between the Republic of Indonesia and the Netherlands over Irian Jaya. The government also issued a policy prohibiting the Stock Exchange from trading securities in Dutch currency. This causes many investors to leave Indonesia. This is the ebb and flow of the old order era.

After the old order ended and the new order was replaced, the first step taken by the government was to restrain and bring the Indonesian economy back to normal. Finally, the Money and Capital Market Preparation Team (PUM) was formed. The New Order government was also serious about reviving the money and capital markets in Indonesia. In the new order era, the development of the capital market was divided into 2 periods, namely in the period 1977-1987 the development of the stock exchange did not produce the expected results. Therefore, the government finally gave concessions to various existing regulations. In the period 1988-1997 the stock exchange became more active, until before the monetary crisis.

During the Reformation era, there were 4 important events that can be recorded as the history of the capital market in Indonesia. The 4 events included: Monetary crisis, index breaking through 4 digits, stock exchange consolidation, and changing names. During the monetary crisis, stock indexes fell from the 700 s to the 200s. In addition, the number of investors has shrunk drastically to only 50 thousand investors. These times can be said to be like a period of mourning for the world capital market in Indonesia. However, with such an incident, capital market players can become more realistic. Securities companies have begun to aggressively attract investors, and Investment Manager companies (Mutual Funds) have become more creative. Now, at the beginning of 2018, the Composite Stock Price Index has reached more than 6,000 . This figure is an extraordinary achievement since the crisis that made the index in the 200's. The JCI also penetrated 4 digits, also deserves to be recorded as an important history of the Stock Exchange. Another important history is the fusion of the Jakarta Stock Exchange and the Surabaya Stock Exchange into one, namely the Indonesia Stock Exchange.

There are 48 Property, Real Estate

and Building Construction Sector Companies listed on the Indonesia Stock Exchange (IDX) for the 2016-2018 period, but in this study only 44 companies.

\section{Descriptive Statistical Analysis}

Descriptive statistical analysis is used to determine the description of a data viewed based on the minimum, maximum, average and standard deviation values. The variables used include the current ratio (CR), debt to equity ratio (DER), price to book value (PBV) and return on equity (ROE).

Based on the data, it is known that the minimum value of the $\mathrm{CR}$ is 0.394 , while the maximum value of CR is 12.769 . 
Lina Minah et.al. Effect of current ratio and debt to equity ratio on price to book value with return on equity as a mediation variable in property, real estate and building construction sector companies on the Indonesia stock exchange for the period 2016-2018.

This means that the minimum value of the current ratio of property and real estate companies that became the research sample from 2016-2018 was 0.394 at the Duta Anggada Realty Tbk company with the company code DART and the maximum value of 12.7690 at the Puradelta Lestari Tbk company with the code DMAS company. The maximum increase/growth of the current ratio in the 2016-2018 research period was 8,123 , which was at the Lippo Cikarang Tbk company with the code LPCK, and the minimum CR increase/growth in the 2016-2018 research period was -6,969, which was at the Greenwood Sejahtera Tbk company with GWSA code.

It is known that the minimum value of the DER is 0.0433 , while the maximum value of DER is 5.2633. This means that the minimum DER of Property and Real Estate Companies that are sampled for research from 2016-2018 is 0.0433 at the Puradelta Lestari Tbk company with the company code DMAS and the maximum value of 5.2633 is at the company Acset Indonusa Tbk with the company code ACST. The maximum increase/growth of the DER in the 2016-2018 research period is 4.256, which is at the Plaza Indonesia Realty Tbk company with the code PLIN, and the increase/growth of the Minimum DER in the 2016-2018 research period is -2.03, which is at the company Agung Podomoro Land Tbk. with APLN code.

It is known that the minimum value of PBV is 0.1055 , while the maximum value of $\mathrm{PBV}$ is 11.189. This means that the minimum price to book value of property and real estate companies that were sampled from 2016-2018 was 0.1055 at the Agung Podomoro Land Tbk company with the company code APLN and a maximum value of 11,189 at the Plaza Indonesia realty company with PLIN company code. The maximum increase/growth in Price to Book value in the $2016-2018$ research period is 2.15, which is at the Sitara Propertindo Tbk company with the TARA code, and the Minimum Price to Book Value increase/growth in the 2016-2018 research period is -2.24 , which is at the Metropolitan Kentjana Tbk company with the MKPI code.

\section{Hypothesis Test}

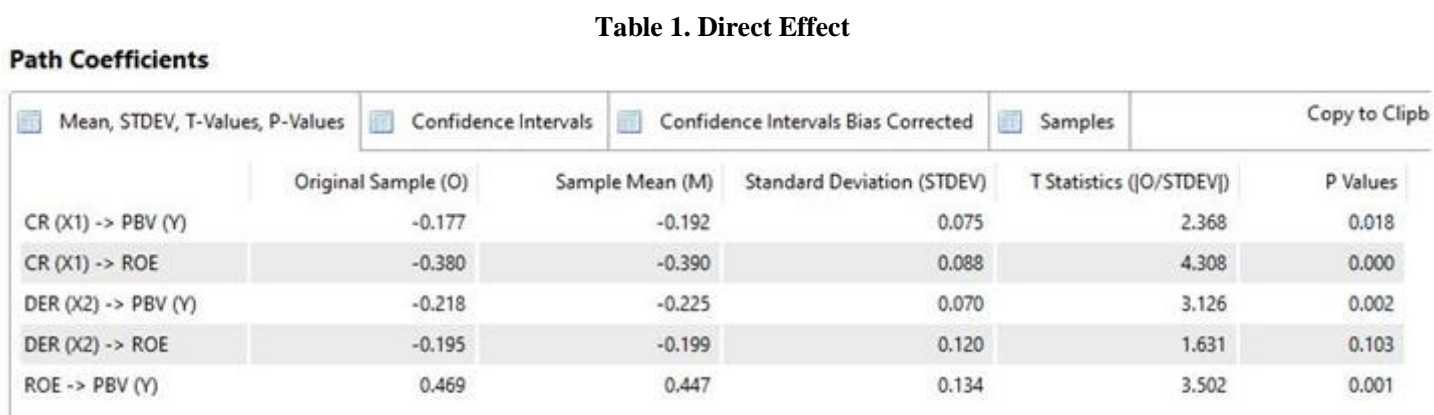

Table 2. Mediation Test

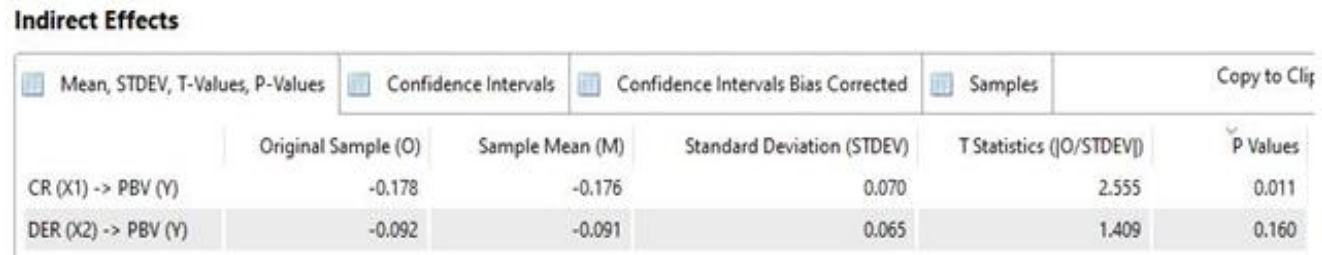

Hypothesis testing to test the significance of the direct effect. This analysis was carried out by comparing the $\mathrm{p}$-value with a significance value of $5 \%$.
The hypothesis is accepted (supported) if the $\mathrm{p}$-value is smaller than the 0.05 significance value. Table 1 and 2 present the results of hypothesis testing based on the 
Lina Minah et.al. Effect of current ratio and debt to equity ratio on price to book value with return on equity as a mediation variable in property, real estate and building construction sector companies on the Indonesia stock exchange for the period 2016-2018.

SmartPLS software for testing the direct effect. The purpose of this study was to determine and analyze the effect of current ratio (CR) and debt to equity ratio (DER) on price to book value (PBV) with return on equity (ROE) as a mediation variable in Property, Real Estate and Building Construction Sector Companies on the Indonesia Stock Exchange for the Period 2016-2018.

Based on the results of hypothesis testing conducted with the SmartPLS tool, it is obtained as follows:

1. CR has significant effect on PBV in Property, Real Estate and Building Construction Sector Companies on the Indonesia Stock Exchange for the Period 2016-2018.

2. DER has an significant effect on PBV in Property, Real Estate and Building Construction Sector Companies on the Indonesia Stock Exchange for the Period 2016-2018.

3. CR has significant effect on ROE in Property, Real Estate and Building Construction Sector Companies on the Indonesia Stock Exchange for the Period 2016-2018.

4. DER has no significant effect on ROE in Property, Real Estate and Building Construction Sector Companies on the Indonesia Stock Exchange for the Period 2016-2018.

5. ROE has significant effect on PBV in Property, Real Estate and Building Construction Sector Companies on the Indonesia Stock Exchange for the Period 2016-2018.

6. ROE has significant effect on mediating the effect of the CR on PBV in Property, Real Estate and Building Construction Sector Companies on the Indonesia Stock Exchange for the Period 20162018.

7. ROE has no effect in mediating the effect of the DER on PBV in Property, Real Estate and Building Construction Sector Companies on the Indonesia Stock Exchange for the Period 20162018.

\section{CONCLUSION AND SUGGESTION}

Based on the results of hypothesis testing conducted with the SmartPLS tool, it is obtained as follows:

1. Current ratio (CR) has significant effect on price to book value (PBV) in Property, Real Estate and Building Construction Sector Companies on the Indonesia Stock Exchange for the Period 2016-2018.

2. Debt to equity ratio (DER) has an significant effect on PBV in Property, Real Estate and Building Construction Sector Companies on the Indonesia Stock Exchange for the Period 20162018.

3. CR has significant effect on return on equity (ROE) in Property, Real Estate and Building Construction Sector Companies on the Indonesia Stock Exchange for the Period 2016-2018.

4. DER has no significant effect on ROE in Property, Real Estate and Building Construction Sector Companies on the Indonesia Stock Exchange for the Period 2016-2018.

5. ROE has significant effect on PBV in Property, Real Estate and Building Construction Sector Companies on the Indonesia Stock Exchange for the Period 2016-2018.

6. ROE has significant effect on mediating the effect of the CR on PBV in Property, Real Estate and Building Construction Sector Companies on the Indonesia Stock Exchange for the Period 20162018.

7. ROE has no effect in mediating the effect of the DER on PBV in Property, Real Estate and Building Construction Sector Companies on the Indonesia Stock Exchange for the Period 20162018.

Based on the results of the study, the researchers suggest that:

1. Management needs to know the elements that become a mirror for the company. The elements that will be assessed by outsiders or investors. In this study, companies must pay attention 
Lina Minah et.al. Effect of current ratio and debt to equity ratio on price to book value with return on equity as a mediation variable in property, real estate and building construction sector companies on the Indonesia stock exchange for the period 2016-2018.

to PBV and ROE, because investors will see a company's ROE before investing. and a good ROE will give a good PBV effect.

2. Companies are required to know the relationship between one element with another element (elements that influence each other).

3. Companies in maintaining the good name of the company are of course obliged to maintain internal operational stability, namely between existing cash and those that will be used for debt payments.

4. Improving performance in managing the use of debt means that the use of debt is really done only to increase business by really paying attention to interest expenses. The interest expense incurred does not cause the fix cost to be higher.

\section{Acknowledgement: None}

\section{Conflict of Interest: None}

\section{Source of Funding: None}

\section{REFERENCES}

1. Brigham, E. F \& Houston, J. F. (2006). Manajemen Keuangan. Edisi Kedua. Jakarta: Kencana.

2. Dunanti, Indri, Darwin Lie, Efendi \& Ady Inrawan. (2017). Pengaruh Likuiditas dan Profitabilitas terhadap Nilai Perusahaan Sub Sektor Property dan Real Estate yang Terdaftar di Bursa Efek Indonesia. Jurnal Manajemen dan Kewirausahaan.

3. Hasibuan, Bosar. (2016). Pengaruh Current Rasio, Return on Equity, TATO terhadap PBV dengan Size Perusahaan sebagai Variable Moderating (Study pada Perusahaan Customer Goods yang terdaftar di BEI Tahun 2009-2013).

4. Isnarno, Endi. (2012). Analisis Pengaruh Current Ratio (CR), Debt to Equity Ratio (DER), Total Asset Turnover (TAT) dan Size terhadap Return on Equity (ROE) dengan Institutional Ownership (INSTOWN) sebagai
Variabel Moderating (Studi pada Perusahaan Animal Feed and Husbandry yang Terdaftar di BEI).

5. Pandiangan, Saut Maruli Tua. (2018). Analisis Faktor-faktor yang Mempengaruhi Penawaran Tenaga Kerja Lanjut Usia di Kota Medan. Tesis. Medan: Fakultas Ekonomi dan Bisnis, Program Studi Ilmu Ekonomi, Universitas Sumatera Utara. http://repositori.usu.ac.id/bitstream/hand le/123456789/10033/167018013.pdf?se quence $=1 \&$ isAllowed $=\mathrm{y}$.

6. Pandiangan, Saut Maruli Tua, Rujiman, Rahmanta, Tanjung, Indra I., Darus, Muhammad Dhio, \& Ismawan, Agus. (2018). An Analysis on the Factors which Influence Offering the Elderly as Workers in Medan. IOSR Journal of Humanities and Social Science (IOSRJHSS), 23(10), 76-79. DOI: 10.9790/0837-2310087679.

http://www.iosrjournals.org/iosrjhss/papers/Vol.\%2023\%20Issue10/Vers ion-8/K2310087679.pdf.

7. Pongrangga, Rizki Adriani, Moch. Dzulkiron \& Muhammad Saifi. (2015). Pengaruh Current Ratio, Total Asset Turnover dan Debt to Equity Ratio terhadap Return on Equity (Studi pada Perusahaan Sub Sektor Propertydan Real Estate yang Terdaftar di BEI periode 2011-2014).

8. Puteh, Anwar. (2013). Pengaruh Current Ratio dan Total Assets Turnover terhadap Return on Equity pada Perbankan yang Terdaftar di Bursa Efek Indonesia. Semnas Fekon: Optimisme Ekonomi Indonesia 2013, antara Peluang dan Tantangan.

9. Sudaryo, Yoyo \& Ika Yanuar Pratiwi. (2016). Pengaruh Struktur Modal dan Likuiditas terhadap Profitabilitas dan Dampaknya terhadap Kinerja Keuangan (Studi Kasus pada Perusahaan Property, Real Estate and Building Construction yang terdaftar di BEI LQ 45 periode 2007-2014).

10. Sutrisno, Wahyu Adi \& Yulianeu. (2017). Pengaruh Current Rasio, Debt to 
Lina Minah et.al. Effect of current ratio and debt to equity ratio on price to book value with return on equity as a mediation variable in property, real estate and building construction sector companies on the Indonesia stock exchange for the period 2016-2018.

Equity rasio dan TATO terhadap PBV dengan ROA sebagai Variable Intervening (Study pada Perusahaan Property dan Real Estate yang Terdaftar di BEI tahun 2010-2014).

11. Uzliawati, Lia, Nana Nofianti \& Dwi Putri Ratnasari. (2016). Struktur Modal, Investment Opportunity Set, Likuiditas dan Nilai Perusahaan. Jurnal Keuangan dan Perbankan.
How to cite this article: Minah L, Toni N, Simorangkir EN, Hutagalung G. Effect of current ratio and debt to equity ratio on price to book value with return on equity as a mediation variable in property, real estate and building construction sector companies on the Indonesia stock exchange for the period 2016-2018. International Journal of Research and Review. 2021; 8(9): 72-80. DOI:https://doi.org/10.52403/ijrr.20210911 